\begin{tabular}{|c|c|c|}
\hline \multicolumn{3}{|c|}{ Efficient Vol 1 (3) (2018): 224-229 DOI: https://doi.org/10.15294/efficient.vii3.27874 } \\
\hline & $\begin{array}{l}\text { Indonesian Journal of Development Economics } \\
\text { https://journal.unnes.ac.id/sju/index.php/efficient }\end{array}$ & \\
\hline
\end{tabular}

\title{
Faktor-Faktor Yang Mempengaruhi Impor Kedelai di Indonesia
}

\author{
Ganang Sukma Buana', Rusdarti \\ Jurusan Ekonomi Pembangunan,Fakultas Ekonomi, Universitas Negeri Semarang \\ Permalink/DOI: https://doi.org/10.15294/efficient.vii3.27874 \\ Received: April 2018; Accepted: July 2018 ; Published: October 2018
}

\begin{abstract}
This study aims to determine the effect of independent variables (soybean production, soybean consumption, gross domestic product, local soybean price and imported soybean price) to the dependent variable (import of soybean) both in the short and long term. This study uses time series or time series data. The analytical model used is an econometric analysis tool error correction model ECM and OLS. This model can explain both short-term and long-term behavior. The result of the research shows that (1) the production variable in the short term does not have an effect, while in the long run it has negative and significant effect to the import of Indonesian soybean. (2) consumption variables in the short and long term have a positive and significant influence to Indonesian soybean import. (3) Gross domestic product in both the short and long term do not affect the import of soybean. (4) local price variables in the short and long term have a positive and significant effect on Indonesian soybean import. (5) import price variable in the short term has a negative effect while in the long term does not affect the import of Indonesian soybean.
\end{abstract}

Keywords: Import, Soybean, ECM

\begin{abstract}
Abstrak
Penelitian ini bertujuan untuk mengetahui pengaruh variabel independen (produksi kedelai, konsumsi kedelai, produk domestik bruto, harga kedelai lokal dan harga kedelai impor) terhadap variabel dependen (impor kedelai) baik dalam jangka pendek maupun jangka panjang. Penelitian ini menggunakan data runtun waktu atau time series. Model analisis yang digunakan adalah alat analisis ekonometrika model koreksi kesalahan ECM dan OLS. Model ini dapat menjelaskan perilaku jangka pendek maupun jangka panjang. Hasil penelitian menunjukkan (1) variabel produksi dalam jangka pendek tidak berpengaruh sedangkan pada jangka panjang berpengaruh negatif dan signifikan terhadap impor kedelai Indonesia. (2) variabel konsumsi dalam jangka pendek maupun jangka panjang berpengaruh positif dan signifikan terhadap impor kedelai Indonesia. (3) Variabel produk domestik bruto dalam jangka pendek maupun jangka panjang tidak berpengaruh dengan impor kedelai. (4) variabel harga lokal dalam jangka pendek maupun jangka panjang berpengaruh positif dan signifikan terhadap impor kedelai Indonesia. (5) variabel harga impor dalam jangka pendek berpengaruh negatif sedangkan pada jangka panjang tidak berpengaruh terhadap impor kedelai Indonesia.
\end{abstract}

\section{Kata Kunci: Impor, Kedelai, ECM}

How to Cite: Buana, G., \& Rusdarti, R. (2018). Faktor-Faktor Yang Mempengaruhi Impor Kedelai di Indonesia.

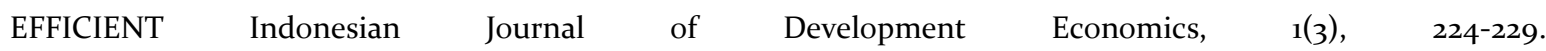
https://doi.org/10.15294/efficient.vii3.27874

(C) 2018 Semarang State University. All rights reserved

Alamat Korespondensi :

Alamat: Gedung L2 Lantai 2 FE Unnes

Kampus Sekaran, Gunungpati, Semarang, 50229

E-mail : efficientjournal@gmail.com 


\section{PENDAHULUAN}

Sebagai negara agraris, pertanian di Indonesia merupakan sektor yang berperan besar dalam pertumbuhan ekonomi. Selain itu, pertanian juga memegang peran penting dari keseluruhan perekonomian nasional. Pertanian memiliki dua pengertian yaitu arti luas dan arti sempit. Pertanian dalam arti sempit merupakan usaha pertanian keluarga dimana di produksi bahan makanan utamanya, sedangkan pertanian dalam arti luas dibedakan menjadi lima sektor yaitu tanaman pangan, perkebunan, perternakan, perikanan, dan kehutanan. Sektor pertanian menyumbang sekitar $25 \%$ dari produk domestik bruto tahun 1981. Angka ini lebih rendah dibandingkan tahun 1972 yang sekitar $40 \%$.

Hal ini berarti terjadi perkembangan yang cukup pesat bukan dari kegiatan pertanian. Tanaman pangan merupakan separuh lebih sumbangan yang diberikan pada sektor pertanian. Walaupun mengalami penurunan, tapi dalam sektor pertanian masih terus memiliki peran penting dalam kehidupan bangsa ini. Diperkirakan sekitar $75 \%$ secara langsung penduduk negeri ini masih bergantung pada sektor tersebut, kirakira 60\% dari tenaga kerja di Indonesia terlibat dalam kegiatan pertanian.

Disamping itu, laju pertumbuhan penduduk yang tinggi menyebabkan semakin meningkatnya kebutuhan akan bahan pangan (Puslitbangtan, 1983:5). Besarnya penduduk Indonesia akan meningkatkan kebutuhan pangan dalam negeri. Peningkatan jumlah penduduk setiap tahunnya, akan diikuti oleh peningkatan daya beli masyarakat yang akan mendorong peningkatan konsumsi pangan. Salah satu komoditas pangan yang akan diangkat dalam penelitian ini adalah kedelai. Kedelai merupakan salah satu komoditas pangan strategis, selain sebagai sumber protein yang menyehatkan, harganya juga murah. Adapun hasil olahan dari komoditas kedelai sebagai bahan makanan yang menghasilkan tahu, tempe, tauco, oncom dan susu kedelai.

Setiap tahun kedelai mengalami peningkatan permintaan. Impor kedelai yang semakin meningkat tajam dalam 10 tahun terakhir terjadi pada tahun 1981 dari 361 ton menjadi sekitar 541 ton pada tahun 1990.

Sementara impor kedelai tertinggi terjadi pada tahun 2011 sebesar 2092 ton. Hal ini disebabkan produksi kedelai yang tidak stabil cenderung mengalami fluktuasi setiap tahun, sementara untuk konsumsi juga terjadi fluktuasi setiap tahun, sehingga impor masih menjadi cara untuk memenuhi kebutuhan kedelai dalam negeri.

Pertumbuhan kedelai yang dinilai lamban, disebabkan oleh lebih dicurahkan perhatian untuk produksi beras, yang merupakan sebagai sumber utama protein bagi masyarakat Indonesia. Padahal justru kedelai banyak digunakan oleh masyarakat untuk konsumsi pangan. Penggunaan kedelai sebagai bahan baku industri olahan pangan menyebabkan konsumsi kedelai semakin tidak menentu, cenderung fluktuasi di setiap tahun. Berikut ini dapat dilihat perkembangan produksi, 
konsumsi, dan impor kedelai di Indonesia tahun $2001-2015$ pada tabel 1.

Tabel 1. Data Impor Kedelai, Produksi Kedelai dan Konsumsi Kedelai Indonesia tahun 20012015

\begin{tabular}{llll}
\hline Tahun & $\begin{array}{l}\text { Impor } \\
\text { (ton) }\end{array}$ & $\begin{array}{l}\text { Produksi } \\
\text { (ton) }\end{array}$ & $\begin{array}{l}\text { Konsumsi } \\
\text { (ton) }\end{array}$ \\
\hline 2001 & 1.160 .000 & 826.932 & 1.962 .163 \\
2002 & 1.360 .000 & 673.056 & 1.832 .027 \\
2003 & 1.100 .000 & 671.600 & 1.675 .580 \\
2004 & 1.200 .000 & 723.483 & 1.640 .176 \\
2005 & 1.200 .000 & 808.353 & 1.703 .853 \\
2006 & 1.310 .000 & 747.611 & 1.583 .731 \\
2007 & 1.160 .000 & 592.534 & 1.712 .623 \\
2008 & 1.390 .000 & 775.710 & 1.647 .872 \\
2009 & 1.680 .000 & 974.512 & 2.295 .677 \\
2010 & 1.850 .000 & 907.031 & 2.651 .871 \\
2011 & 1.800 .000 & 851.286 & 2.944 .320 \\
2012 & 1.800 .000 & 843.153 & 3.056 .693 \\
2013 & 2.240 .000 & 779.992 & 2.199 .286 \\
2014 & 2.450 .000 & 954.997 & 2.547 .285 \\
\hline
\end{tabular}

Sumber : BPS Indonesia

Dari tabel di atas, dapat dilihat bahwa untuk memenuhi permintaan kedelai dalam negeri, lebih banyak dengan melakukan impor. Hal ini berarti Indonesia memiliki ketergantungan impor kedelai yang cukup tinggi dikarenakan jumlah kedelai yang diimpor lebih banyak daripada produksi Indonesia.

\section{METODE PENELITIAN}

Jenis data yang digunakan dalam penelitian ini dikategorikan sebagai data sekunder yang diperoleh dari beberapa sumber dengan cara mengambil data-data statistik yang telah ada serta dokumen-dokumen lain yang terkait dan yang diperlukan.

Data yang dikumpulkan berupa data volume beserta nilai impor kedelai, produksi kedelai domestik, harga kedelai domestik dan nilai tukar Rupiah terhadap Dollar Amerika. terhadap Dollar Amerika. Data tersebut diperoleh dari Badan Pusat Statistik (BPS), Departemen Pertanian, Food and Agriculture Organization (FAO) dan International Monetary Found (IMF) serta penelitianpenelitian terdahulu yang terkait dengan penelitian ini. Dan juga melalui Referensi studi kepustakaan melalui jurnal, artikel, perpustakaan UNNES Universitas Negeri Semarang dan internet yang masih relevan dengan penelitian ini.

Peneliti menggunakan metode analisis model ECM (Error Correction Model) Engle Granger untuk mengolah data dalam penelitian ini. Alasan penggunaan metode analisis ECM adalah bahwa metode ini bisa menggambarkan suatu model dinamis dalam perekonomian yang berkaitan dengan waktu penelitian baik dalam jangka panjang maupun jangka pendek dan untuk menghindari kesalahan ekuilibrium (equilibrium eror). Manfaat dari penggunaan model dinamis sendiri adalah untuk menghindari masalah regresi lancung (spurious regression). Suatu regresi linear dikatakan lancung bila anggapan dasar klasik regresi linier tidak terpenuhi.

\section{HASIL DAN PEMBAHASAN}

Berdasarkan hasil penelitian yang sudah dilakukan diperoleh bahwa model terbaik yang digunakan dalam penelitian ini adalah model regresi liner berganda dengan persamaan berikut 
Lny $=98778.71-0.244484 \ln x 1 t+0.476642$ $\ln x 2 t-314.7632 \ln x 3 t+204.0444 \ln x 4 t+$ $2.699348 \ln x 5$

Uji akar unit pada level-intercept diperoleh hasil bahwa semua variabel tidak stasioner. Untuk itu dilakukan uji integrasi agar diperoleh data stasioner. Uji integrasi semua variabel yang digunakan dalam penelitian ini stasioner pada tingkat yang sama pada differensial 1. Uji kontegrasi diperoleh bahwa nilai statistik ADF lebih kecil dari nilai kritis 1\%, 5\% dan $10 \%$ atau dilihat dari probabilitas yang signifikan $(0,00<0,05)$ maka semua variabel baik variabel independen dan variabel dependen terkointegrasi.

Regresi jangka panjang diperoleh hasil model hasil regresi jangka pendek adalah sebagai berikut.

DLIMPORt $=453-1,10$ DLPRODUKSIt + 0,26 DLKONSUMSIt + 69,3 DLPDBt + 139 DLHARGALOKALt - 143 DLHARGAIMPORt o,72 ECT

Sementara regresi jangka panjang diperoleh hasil model hasil regresi jangka panjang adalah sebagai berikut.

LIMPORt $=-987-0,24$ LPRODUKSIt + 0,47 LKONSUMSIt - 314 LPDBt + 204 LHARGALOKALt + 2,69 LHARGAIMPORt + et

Uji t jangka pendek diperoleh bahwa nilai t hitung produksi sebesar -0.499626 lebih kecil dari t-tabel 1.70814 dengan $\alpha=5 \%$ dan nilai koefisien sebesar -0.105452 yang bernilai negatif tidak mempunyai pengaruh terhadap impor kedelai. Kemudian dalam jangka panjang variabel produksi mempunyai pengaruh negatif dan signifikan terhadap perubahan impor kedelai Indonesia dilihat dari t hitung sebesar $\mathbf{- 1 . 7 2 1 3 2 0}$ lebih besar dari ttabel 1.70814 dengan $\alpha=5 \%$ dengan nilai koefisien sebesar -0.244484. Jangka pendek konsumsi nilai t hitung sebesar 2.703747 lebih besar dari t-tabel 1.70814 dengan $\alpha=5 \%$ dan nilai koefisien sebesar 0.265601 yang bernilai positif dan mempunyai pengaruh terhadap impor kedelai. dalam jangka panjang variabel konsumsi mempunyai pengaruh negatif dan signifikan terhadap perubahan impor kedelai Indonesia dilihat dari t hitung sebesar 4.104536 lebih besar dari t-tabel 1.70814 dengan $\alpha=5 \%$ dengan nilai koefisien sebesar 0.476642 . Jangka pendek PDB nilai $t$ hitung sebesar 0.141408 lebih kecil dari t-tabel 1.70814 dengan $\alpha=5 \%$ dan nilai koefisien sebesar 69.31890 yang bernilai positif tidak mempunyai pengaruh terhadap impor kedelai. dalam jangka panjang variabel PDB tidak berpengaruh terhadap perubahan impor dilihat dari nilai $\mathrm{t}$ hitung sebesar -0.795331 lebih kecil dari t-tabel 1.70814 dengan $\alpha=5 \%$ dan nilai koefisien sebesar -314.7632 yang bernilai negatif tidak mempunyai pengaruh terhadap impor kedelai. Jangka pendek harga lokal nilai t hitung sebesar 1.690863 lebih besar dari t-tabel 1.70814 dengan $\alpha=5 \%$ dan nilai koefisien sebesar 139.0827 yang bernilai positif dan mempunyai pengaruh terhadap impor kedelai. Kemudian dalam jangka panjang variabel harga kedelai lokal mempunyai pengaruh positif dan signifikan terhadap perubahan impor kedelai Indonesia dilihat dari t hitung sebesar 2.505226 lebih besar dari ttabel 1.70814 dengan $\alpha=5 \%$ dengan nilai koefisien sebesar 204.0444. Jangka pendek harga impor nilai t hitung sebesar -2.392942 
lebih besar dari t-tabel 1.70814 dengan $\alpha=5 \%$ dan nilai koefisien sebesar -143.6458 yang bernilai negatif dan mempunyai pengaruh terhadap impor kedelai. Kemudian dalam jangka panjang variabel harga kedelai impor mempunyai pengaruh positif dan signifikan terhadap perubahan impor kedelai Indonesia dilihat dari thitung sebesar 0.035585 lebih kecil dari t-tabel 1.70814 dengan $\alpha=5 \%$ dengan nilai koefisien sebesar 2.699348 .

Berdasarkan pengolahan data jangka pendek dengan pendekatan Error Corection Model diperoleh nilai adjustedR sebesar 0.9210490 .649761 yang artinya 64.9 persen dari variasi variabel terikat mampu dijelaskan oleh variasi himpunan variabel penjelas. Sementara sisanya 35.1 persen variasi variabel terikat dijelaskan oleh variabel lain di luar model. Hasil estimasi jangka panjang memiliki nilai adjustedR sebesar 0.921049 yang artinya 99.1 persen dari variasi variabel terikat mampu dijelaskan oleh variasi himpunan variabel penjelas. Sementara sisanya 7.9 persen variasi variabel terikat dijelaskan oleh variabel lain di luar model.

\section{SIMPULAN}

Berdasarkan hasil yang didapatkan dari penelitian yang dilakukan terhadap faktorfaktor yang mempengaruhi impor beras di Indonesia tahun 1985-2015 dengan pendekatan Error Correction Model (ECM) jangka pendek/panjang dan Asumsi Klasik didapatkan kesimpulan bahwa produksi kedelai Indonesia dalam jangka pendek tidak berpengaruh terhadap perubahan impor kedelai di Indonesia, sedangkan pada jangka panjang Produksi kedelai Indonesia berpengaruh negatif dan signifikan terhadap perubahan impor kedelai di Indonesia. Konsumsi kedelai Indonesia dalam jangka pendek dan jangka panjang berpengaruh positif dan signifikan terhadap perubahan impor beras di Indonesia. PDB dalam jangka pendek dan jangka panjang tidak berpengaruh dan signifikan terhadap perubahan impor beras di Indonesia. Harga kedelai lokal dalam jangka pendek dan jangka panjang berpengaruh positif dan signifikan terhadap perubahan impor beras di Indonesia. Harga kedelai impor dalam jangka pendek berpengaruh negatif dan signifikan terhadap perubahan impor kedelai di Indonesia, sedangkan pada jangka panjang harga kedelai impor tidak berpengaruh terhadap perubahan impor kedelai di Indonesia.

Melihat hasil dari penelitian diatas produksi kedelai pada jangka panjang berpengaruh negatif dan signifikan terhadap impor kedelai Indonesia. Peran pemerintah dalam melindungi produk kedelai dalam negeri sangat dibutuhkan, seperti lebih mengutamakan produk kedelai dalam negeri di banding produk kedelai impor sehingga pasar kedelai dapat dikuasai oleh produk kedelai dalam negeri. Dengan demikian konsumsi kedelaipun dapat terpenuhi tanpa melakukan impor. Konsumsi kedelai di Indonesia berpengaruh positif dan signifikan, sehingga perlunya tambahan produksi kedelai Indonesia untuk memenuhi konsumsi di Indonesia. Seperti point 1, jika point tersebut terlaksana maka kebutuhan/konsumsi kedelai di Indonesia dapat terpenuhi. Harga kedelai lokal berpengaruh positif dan signifikan, akibat meningkatnya harga kedelai lokal maka produsen pengolah kedelai lebih mengutamakan kedelai impor.Banyak faktor yang membuat harga kedelai lokal seperti 
akses petani terhadap pasar, luas lahan pertanian kedelai yang menurun sehingga produksi menurun dan berakibat kelangkaan kedelai, kualitas produk kedelai lokal yang kalah terhadap kedelai impor, dll. Maka pemerintah perlu melihat lebih dalam kendala-kendala yang di hadapi oleh petani kedelai sehingga harga kedelai lokal dapat bersaing dengan harga kedelai impor dan pasar kedelai Indonesia tidak dibanjiri oleh produk kedelai impor.

\section{DAFTAR PUSTAKA}

Ajija, R. Shochrul., Dyah W, dkk. 2011. Cara Cerdas Menguasai Eviews. Jakarta: Salemba Empat.

Amang, Bedu. 1996. Ekonomi Kedelai di Indonesia. IPB Press: Jakarta.

BPS. 2015. Tanaman Pangan. Jakarta : Badan Pusat Statistik

Debertin David L. (2012) Agricultural Production Economics Second Edition, Pearson Education, New Jersey

Fakultas Ekonomi UNNES. 2015. Pedoman Penulisan Skripsi. Semarang: Departemen Pendidikan dan Kebudayaan.
FAO. 2015. FAOSTAT. United Nation : Food and Agriculture Organization

Husodo, S. Y., et al. 2004. Pertanian Mandiri. Penebar Swadaya. Jakarta.

Krugman Paul R. Dan Obstfleld Maucire. 2003. Ekonomi Internasional Teori dan Kebijakan. Edisi kelima. PT Indeks Kelompok Gramedia

Lipsey, R.G., P.N. Courant, dkk. 1995. Pengantar Mikroekonomi. J. Wasana dan Kirbrandoko. [penerjemah]. Binarupa Aksara: Jakarta.

Pracoyo, Tri Kunawangsih, dkk. 2005. Aspek Dasar Ekonomi Makro di Indonesia. Jakarta : PT Grasindo.

Purnamasari, Rika. 2006. Analisis Faktor-Faktor Yang Mempengaruhi Produksi dan Impor Kedelai di Indonesia. [skripsi]. Program Studi Ekonomi Pertanian dan Sumberdaya. Fakultas Pertanian. Institut Pertanian Bogor.

Rukmana, R. dan Yuyun Yuniarsih., 1996. Kedelai Budidaya dan pascapanen. Kanisius, Yogyakarta.

Salvatore, D. 1997. Ekonomi Internasional. Haris Munandar. [penerjemah]. Erlangga: Jakarta.

Widarjono, Agus. 2009. Ekonometrika, Pengantar dan Aplikasinya. Yogyakarta: Ekonisia.

Yoesron, Tati Suhartati, dkk. 2003. Teori Ekonomi Mikro. Jakarta : Salemba Empat 